\title{
ISLAM AND HUMAN RIGHTS
}

\section{Tension and Possible Cooperation: The Case of Indonesia* Muhammad A.S. Hikam}

One of the most intriguing questions in the discourse on human rights is wheather or not the world religions, particularly Judaism, Christianity and Islam, are compatible with the modern idea of universal human rights, which is based upon secular philosophy. This question is especially crucial for Islam. When compared to Judaism and Christianity. Islam has been the most misunderstood religion and has become the target of many suspicions based on stereotypes and prejudices. Yet, in fairness, I must say that not all criticisms of Islam are without some grain of truth.

One only needs to recall that it is in the so-called Islamic countries, or Muslimdominated regions, the some of the most serious violations of human rights have taken place. The difficulty in disproving alleged violations of human rights is especially complicated by the refusal of the leaders of those countries to allow independent groups to investigate, or even verify, reports given the press refugees, diplomats, etc.

It is hardly surprising that there is always a certain degree of ambiguity when we talk about the possibility of Islam being utilized to promote human rights. This, in tum, makes it hard, if not impossible, to provide satisfactory answers and workable recommendations. Such ambiguity is discernible primarily in the wide gap between the ideal and the reality. Thus those who hold that Islam could strengthen efforts to promote human rights will base their arguments on the fact that Islam, as a world religion, contains many principles compatible with the universal declaration of human rights. This is because Islam not only provides comprehensive teachings in matters related to religious law (fiqh), dogmas (tauhid) and ethics (akhlaq). but also in matters related to human relations (mu'amalat) and world affairs.

In Islamic teaching, human-and social dimensions (insaniyyah) are considered paramount. The ulama (Islamic scholars), who occupy an important position in Ialam because of their knowledge, have always played plvotal roles in elaborating religious teachings to anticipate and adjust to changing circumtances. From this perspective, Islam can contribute to the discourse and practice of human rights through the continuous elaboration and reinterpretation of its teachings by its scholars and experts.

However, those who are skeptical about the compatibility of Islam with modern univerasl human rights will point to the condition of human rights in many Islamic countries as evidence that.

the religion itself is partly responsible for some violation of human rights. In Indonesia, the Muslim community and its leaders have no choice but to participate

- Muhammad AS Hikam is a Reasearch Fellou at the center for Economic and Development Studies, Indonesia Institute of Science (PEP-LIPI) in Jakarta. 
in the discourse of human rights as an inseperable part of the ongoing democratization processes. Besides, many authoritarian regimes have maintained their power for long time in the name of Islam. In doing so, they have appropriated religious teachings and co-opted many religious leaders to legitimize their repressive power. As a result, prohibitions, of political dissent and free speech, harassment of opposition groups, arrest and imprisonment without warrants, etc. are common practices and often occur with the blessing of some religious leaders.

Outside the political realm, violations of human rights, such as abuses of women and children, discrimination against non-Muslim minorities, and in some areas, the practice of female genital mutilation, are frequently conducted based upon religious decrees (fatwa). Islam is frequently singled out for women rights violations because these acts rely on religious arguments by religious scholars.

Although there are some Islamic principles which may be compatible with the promotion of human rights and democracy, there are also principles which contradict, or are inimical, to the very idea. For instance, the sharp bifurcation between the House of Islam (dar-al Harb) and between the community of belivers (ummah) and the so-called people under protection (ahl-Dzimmah) could pose serious problems to the development of a modern, democratic polity based upon citizenship

This tension between the ideal and reality will always be present and should be addressed openly-Additionaly, to better understand Islam and its potential contributions to the struggles for human rights, one should put the question in particular historical and structural conjunctures within an Islamic community or country. This approach will enable us to grasp existing tensions between the ideal and reality and avoid the pitfall of over generalization.

\section{The Case of Indonesia}

In Indonesia. the Muslim community and its leaders have no choice but to participate in the discourse of human rights as an inseparable part of the ongoing democratization processes. As in other parts of the Muslim world. Indonesian Muslims are facing the underlying tension between religious tenets and the existing social, political and economics realities which are not always conducive to the realization of those beliefs.

Also, the dynamics of modern Islamic movements for the past 70 years have left an indelible mark on Indonesian Islam, namely in the plurality of organizations, ideas and strategies. Consequently, the issue of human rights and its implementations have incited different responses among Islamic groups in the country.

Abdurrahman Wahid, a leading Muslim intellectual in Indonesia and the general chairman of Nahdatul Ulama (NU), the largest Islamic organization in the country. argues that the role played by Islam in the fleld of human rights in Indonesia is determined by the dynamic tensions among three interconnected poles. The first pole is Islam as a religion whose universal claims encompass the realm of human rights: the second pole is the modern, secular-based concept of universal human rights; and the third pole is the state's own interpretation of human rights principles in accordance with national interests. 
The fact that Islam contains universal principles which may or may not be compatible with the secular-based universal principles of human rihgts is beyond dispute. Because of this, tensions between the first two poles are influenced by the ways in which Islamic groups and leaders interpret such universal principles. Tiley are also influenced by the responses from advocates of the secular-based human rights principles to certain Islamic principles.

Thus, coming to grips with the diversity of opinions and interpretations on basic principles advocated by different groups within the Islamic community is important. For instance, the Islamists maintain that Islamic teaching would never be reconciled with ideas and practices based upon secularist foundations. Yet, for the moderate strands within Islamic movements, such reconsiliation and cooperation between the two are, at least, theoretically possible and worth trying in the real world.

Islamists advocate legal formalistic strategies in implementing their ideas into practice, while moderates advocate transformative and gradual "Coming to grips with the diversity of opinions and interpretations on basic principles advocated by different groups within the Islamic community is important." There are two approaches for inculcating Islamic ethics in society. The first approach is based on the idea that formalization of Islam in all dimensions of life, through laws and supported by the state, is the only option to fully implement Islamic teachings. The necessity of establishing an Islamic state of developing an Islamic society based on Islamic laws (sharl'ah) as a prerequisite is indispensable.

On the contrary, the second approach maintains that the formalization of Islamic teachings by imposing shari'ah is not the only option, and it could be even dangerous in such a pluralist society as Indonesia. Developing a modern society in which Islam will attempt to influence its moral and ethical bases without using legal formalistic means is important. Islam, in this view, is but one among many value systems that exists in society, and should not claim to be the only alternative for the development of the new society.

If we are in agreement with the second approach, then the main task is to determine common ground on which Islam can promote human rights with other forces. It is important to note that according to Nurcholish Majid, a leading Muslim intellectual in Indonesia, both Islamic and Western secular traditions share similar cultural roots- namely, the Abrahamic religious traditions. Western culture and its value system have origins from Judeo-Christian traditions, which in its development informs the existing universal declaration of human rights. Islam also owes some of its sources to the same traditions. Therefore. they are not totally incompatible with each other because, at least, some of their basic principles are not mutually exclusive.

\section{Islamic Principles and the Universal Declaration on Human Rights: Common Ground}

Abdurrahman Wahid has demonstrated that several basic principles in Islam that are commensurate with the universal declaration of human rights can be found in the classical literature on religious laws (al-kutub al-fiqhiyyah). They consist of five principles:1) protection from physical abuses outside the law;2) religious freedom, 
including non-coercion in religion;3) protection of the family and offspring: 4) protection of private property; and 5) protection of one's profession.

The first principle means that the existence of a government based on the rule of law, which guarantees equal treatments to the citizens along with their rights, is necessary. Also, Islam acknowledges the importance of impartiality in law enforceement and the centrality of justice as the foundation of a good society. This principle is undoubtedly similar to the universal declaration of human rights, which regards justice, equality and democracy as the fundamental norms in a democratic policy.

The second principle is commensurate with the universal declaration's idea of religious tolerance. At the heart of Islam is the idea of the Unity of God (at-tawhid). According to an Egyptian philosopher, Hasan Hanafi, the term "tawhid" can be interpreted as "the affirmation of human freedom without any oppression, human equality free from racism, and human justice exempt of social injustice." In Wahid's understanding, this particular freedom should encompass even the realm of faith because Islam respects different religions and acknowledges netther compulsion nor coercion in religious matters, including religious conversion.

The third principle is a moral and ethical foundation upon which, according to Islam, good society can be established. In Islam, the sanctity of the family is the the foundation for community life and, therefore, it should be free from manipulation by outside forces- including society and state. According to Wahid, it is in the family that an individual begins to explore his/her freedom to choose and question, including the freedom to question his religious belief. It is the family that first provides opportunities for him/her to select alternatives which will affect his/her future life.

Finally, it is the family that preserves the existing social cohesion by integrating its members into a larger social unit.

The fourth principle is very crucial in relation to the modern formation of society. Modernization inevitably brings about differentiation of roles and functions, as well as the process of individuation in soclety. The protection of individual rights vis-a-vis social rights gradually becomes a demand in modern life. A clear distinction between the public and the pflivate is needed. Otherwise, the violation of individual rights, in the name of public interests, will be prevalent. One solution is to acknowledge the notion of private property. It is through this right that an individual can exercise personal freedom and develop his/her potentiality. Yet, his/her actions are still within the boundaries set by members of the larger society.

The fifth and last principle is closely related to the fourth. It implies that in respecting individual freedom, Islam opens the door for an individual member of society to choose alternatives relevant to one's life. The principle clearly respects the right to pursue one's goals as a for self-expression. This also means that Islam regards individual responsibility as one of the most valuable elements in social relations.

There is clearly room for the Muslims to work with others to promote human rights, particularly in the areas discussed above. If the Muslims develop programs and 
actions from these principles, they will be able to grapple with the most pressing problems in the field of human rights in many Islamic countries.

\section{National Interest, Islam and Human Right: the State}

This brings us to the tension originating from the third pole, namely the state's interest, I think this is the most challenging problem, especially in Indonesia where Islam has been at the center of domestic political struggles since the country's independence. Under the present regime, for instance, the state has, from time to time, attempted to embrace Islam in order to win support and strengthen its legitimacy and authority. The dynamic relations between Islamic forces and the state will have a tremendous impact on the efforts of Islamic groups willing to work in the field of human rights.

Also, the current phenomenon of Islamic revivalism and resurgence in Indonesia has resulted in several developments whose outcomes are still difficult to predict. Islam has, again, reasserted itself as a potential political force that has to be taken into account by the state and others in Indonesia. It is no surprise that some factions in the ruling elite, for example, have seen the possibility of playing the Islamic card to support their own political agenda, particularly related to the succession issue. Islam, therefore, will be central in the Indonesian political discourse in the years to come, and again it will influence the progress of human rights.

As far as the state is concerned, it is well known that like many governments in the Third World, the New Order has tried to challenge the universality of human rights based on the idea of cultural relativism and the stage of development. It has been argued, for example, that the notion of rights is relative and especially contingent upon specific cultural and religious elements in society. It has also been argued that the implementation of human rights should correlate with the nation's level of economic development.

The appropriations of such a cultural relativism and the valorization of the right to development are mainly used by the existing regime to support its efforts to pursue political stability and economic development as the ultimate national priorities. From the state's vantage point, political and clvil rights should be considered secondary since "they are neither meaningful nor feasible in conditions of want and poverty." As a consequence, the state feels justified when it suppresses those who demand the protection of political and clvil rights, as they would only disturb the acceleration of economic development

The state has defended the vision of cultural relativism concerning universal human rights by approprlating and reinterpreting existing tradi.

tion, cultures and religions. For example, it has been argued that Indonesian culture gives higher value to the community than other cultures. The government has repeatedly stressed that the interests of the community take precedence over those of the individual, particularly when there is conflict between the two. This is usually to legitimize the state, under the pretext of representing the interests of the whole community, to act against individual basic rights.

The use of religtous values in supporting the state is also apparent. For example, the state has attempted to galvanize support from Islamic groups and leaders in order to 
respond to the increasing scrutiny in the field of human rights, domestically and internationally. The case of religiously motivated riots in East Timor may be relevant here. In this case, many Islamic leaders were provoked by incident, which unwittingly caused them to react negatively toward other religious groups. This in turn strengthened the existing prejudice toward Islam among non-Muslims in the province and constrained their relations.

As a result, Islam as a political and social force in Indonesia has been disunited on the issue of human rights partly because of the state's strategy of co-operation. The Islamist groups tend to support the state's reletivist view on human rights for two basic reasons: one is ideological and the other is strategic. The first is their rejection of secular and Western values, while the second is a long-term strategy of Islamizing the political sphere.

In such a political enviornment, advocates of human rights among Islamic groups face increasing pressure from both the state and Islamist groups. Their voices are muted and suppressed by censorship or harassment, making it difficult for them to participate openly in the discourses and practices regarding human rights issues in Indonesia. There are, of course, still some Islamic leaders, such as Abdurrahman Wahid and Norcholish Majid, who dare to express their views and challenge the relativist vision of human rights articulated by both the state and the Islamists. It remains to be seen whether their persistence and tenacity will balance the currently dominant relativist perspective in Indonesia.

\section{Steps Toward Cooperation}

In closing, I would argue that both the Islamic and the modern, secular perspectives on human rights share commonalties reflected in some basic principles. This makes it possible to open the door for reconsiliation and cooperation between them. The questions is how to generate vaible agendas and programs to implement such an idea. Obviously there is no easy answer. However, I have listed below some tentative recommendations which can be further discussed.

The first is the need for extensive education programs at the grassroots level on the basic principles of human rights from both perspectives. Emphasis should be on the effort to disseminate common ground and principles shared by both Islam and the West. The program should be aimed at building awareness among the people about the compatibility of some Islamic principles with the modern concepts of human rights.

Second, an appropriate information delivery system for the promotion of human rights needs to be developed. This can be done, for example, through the existing networks of nongovernmental organizations (NGOS) and social and religious organizations, such as UN and Muhammadiyah. NGOs' access to vartous sources of information, both domestically and internationally, could be very useful.

The social and religious organizations, in the meantime, can play a role as information networks to provide and disseminate relevant information regarding human rights problems. The institutional capacity of such organizations as UN and Muhammadiyah is tremendous, due to the existence of their schools. pesantrens, mosques, etc., throughout the country. 
The third recommendation is to strengthen links between existing agencies working in the field of human rights, such as YLBHI (Legal Add Institute). Yapusham (Centre for Human Rights) and Komnasham (National Human Rights Commission) and those Islamic organizations and leaders who share a similar concern. This is important because these agencies still work sepa.

rately and tend to communicate very little to religious communities. It would be useful, therefore, if they could support and promote dialogue between the religious and the secular groups to better understand each other, particularly in dealing with human rights issues.

Islam is represented by various strands within the field of human rights. Recognizing those that are more appreciative and supportive to the universal declaration of human rights is crucial to overcoming prejudices and stereotypes.

Finally, studies on religlous (Islamic) perspectives on human rights are still lacking in Indonesia. While there has been abundant literature on Islam and politics, the area of human rights is different. Therefore, it is important to support research activities concerning Islam and human rights in both Indonesia and in Asia. This will coutribute to a better understanding of the Islamic world, its complexities, heterogeneity, and difference. Islam is reprenested by various strands within the fleld of human rights. Recognizing those that are more appreciative and supportive to the univerasl declaration of human rights is crucial to overcoming prejudices and stereotypes.

"We have enjolned on man, kindness to his parents; in pain did his mother bear him and in pain did she give him birth; and the bearing of him and the wearing of him is thirty months."

- (Al-gur'an, $46:$ 15) 